\title{
Impact of Sulphur Content on Coal Quality at Delta Plain Depositional Environment: Case study in Geramat District, Lahat Regency, South Sumatra
}

\author{
Siska L. Sari ${ }^{1} *$, M.A Rahmawati ${ }^{1}$, A.Triyoga ${ }^{1}$, Idarwati ${ }^{1}$ \\ ${ }^{1}$ Geological Study Program, Sriwijaya University, Jl. Srijaya Negara, Bukit Besar, Ilir Barat I Palembang 30139
}

* Corresponding author : siskalindasarii@gmail.com.

Tel.: +82-18-695-6119;

Received: May 25, 2017. Revised : July 1, 2017, Accepted: Aug 9, 2017, Published: Sept 1, 2017

DOI : 10.24273/jgeet.2017.2.3.301

\begin{abstract}
The research was conducted in Geramat District of Lahat Regency, South Sumatra. An evaluation of the geological condition of the research area shown that the coal deposits were found in Muara Enim Formation as a coal-bearing formation. The method used was literature study, field observation and the laboratory work includes proximate and petrography analysis. The aim of this research is to determine the environmental condition of coal based on the change of total sulphur content and to know the relation between ash content to calorific value. As the result of proximate analysis conducted on five samples of coal, the research area obtained total sulphur $(0,21-1,54 \% \mathrm{adb})$, ash content $(3,16-71,11 \% \mathrm{adb})$ and gross calorific value (953 - $5676 \mathrm{cal} / \mathrm{g}$. adb). Based on the result of maceral analysis showed the maceral percentage of coal in research area composed by vitrinite $(77,8-87,4 \%$, liptinite $(0,6 \%$, inertinite $(8,0-17,6 \%$ and mineral matter concentration in the form of pyrite (1,6-4,6\%. The average reflectance value of vitrinite (Rv) of coal in the research area $(0.54 \%$. the results analysis shows that the coal in Muara Enim Formation on the research area is in the transitional lower delta plain depositional environment phase. Any changes in the sedimentary environment affected by sea water will be followed by changes in total sulphur and the higher ash content, on the contrary, the lower calorific value of the coal..
\end{abstract}

Keywords: Coal, Depositional Environment, Delta Plain, Sulphur, Geramat District.

\section{Introduction}

Indonesia's coal is known with its low sulphur content, thus affecting the quality of coal. This condition resulted in the coal is in demand in the world market, considered as an environmentalfriendly coal. The establishment of sulphur presence in coal and peat such as (1) Low sulphur content coals $(<1 \%$ ), contains more organic sulphur than pyritic sulphur. Conversely, high sulphur content coals contains more pyritic sulphur than organic sulphur. (2) High sulphur content coals are usually associated with cap rock derived from the marine environment (3) The highest Sulphur content in coal is usually on the roof and floor part (Casagrande, 1987). Sulphur is one of an important factors associated with the depositional environment of coal. The sulphur content contained in coal is expected to be minimal due to causing of air pollution. Sulphur occurs in peat, associated with sea water generally contains higher level of sulphur than fresh water peat.

The characteristic of coal depositional are divided in to five categories which are distinguished based on moisture factor, $\mathrm{pH}$, hydrogen ion concentration, food supply and bacterial activity. According to Diessel (1992) three of them are topogenic peat swamps, which are divided into acid high water-table conditions, neutral high watertable condition and variable water-table condition. The other two are ombrogenic peat swamps, divided into continuously wet and intermittently dry (Fig 1).

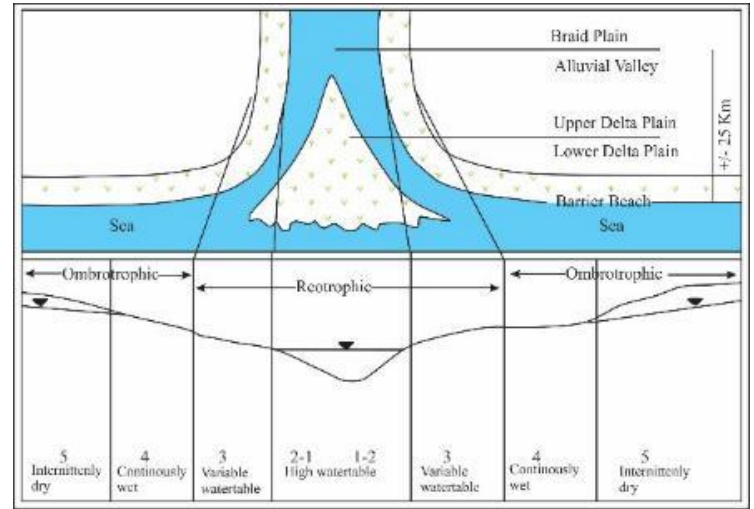

Fig. 1. Modified sketch of depositional environment and peat-accumulated condition (Diessel, 1992)

Determination of coal quality based on depositional environment is related to total sulphur 
content, ash content and calorific value. The higher level of sulphur content in coal indicates its sedimentation in the marine environment while lower sulphur content in coal indicates the depositional environment relatively in land environment. The higher level of ash, the smaller cal orific value of coal and vice versa. The percentage of sulphur content and ash content in coal effects the cal orific value and quality of coal (Cook,1999 in Sulistyana, 2012).

This research aims to determine the relationship of sulphur content and ash content along the calorific value and to perform a depositional environment analysis towards organic material.

The study was located in Geramat District, Lahat Regency South Sumatera as a part of South Sumatera Basin. The local stratigraphy of research area consist of Air Benakat Formation, Muara Enim Formation, Kasai Formation and Andesit Unit (Fig. 2).

\section{Regional Geology}

South Sumatera Basin is a back-arc sedimentary basin bounded by Barisan Mountains in the Southwest, Sunda Shelf in the Northeast, Lampung High in the Southeast and Tigapuluh Mountains splitting the basin from the Central Sumatera Basin. the regional stratigraphy of South Sumatra basin began from Eocene to Quartenary (de Coster,1974). Regional stratigraphic unit's detail of South Sumatra Basin can be seen in (Fig 3). (a) Basement Rocks

The basement rocks of South Sumatra Basin is a complex of Mesozoic igneous rock al ong with Paleozoic and Mesozoic metamorphics and carbonates. The Paleozoic and Mesozoic metamorphic and sedimentary rocks were sustained intensely by the tectonism stress resulted in the rocks to be folded and faulted and were intruded by igneous rocks during the Middle Mesozoic Orogeny.

(b) Lahat Formation

Lahat Formation deposited in Early Tertiary, in the Late Eocene to the Early Oligocene. It was considered as an initial deposition and was deposited on the Pre-Tertiary unconformity surface. Lahat Formation consisted of tuffaceous sandstone, conglomerate, breccia and claystone. These rocks are product of continental sedimentation and volcanism in Early Tertiary tectonism.

(c) Talang Akar Formation

Talang Akar Formation has been dated in Late Oligocene to Early Miocene by its stratigraphy position beneath the well dated Basal Telisa Limestone member. It consisted of sandstone and claystone, deposited in delta environment.

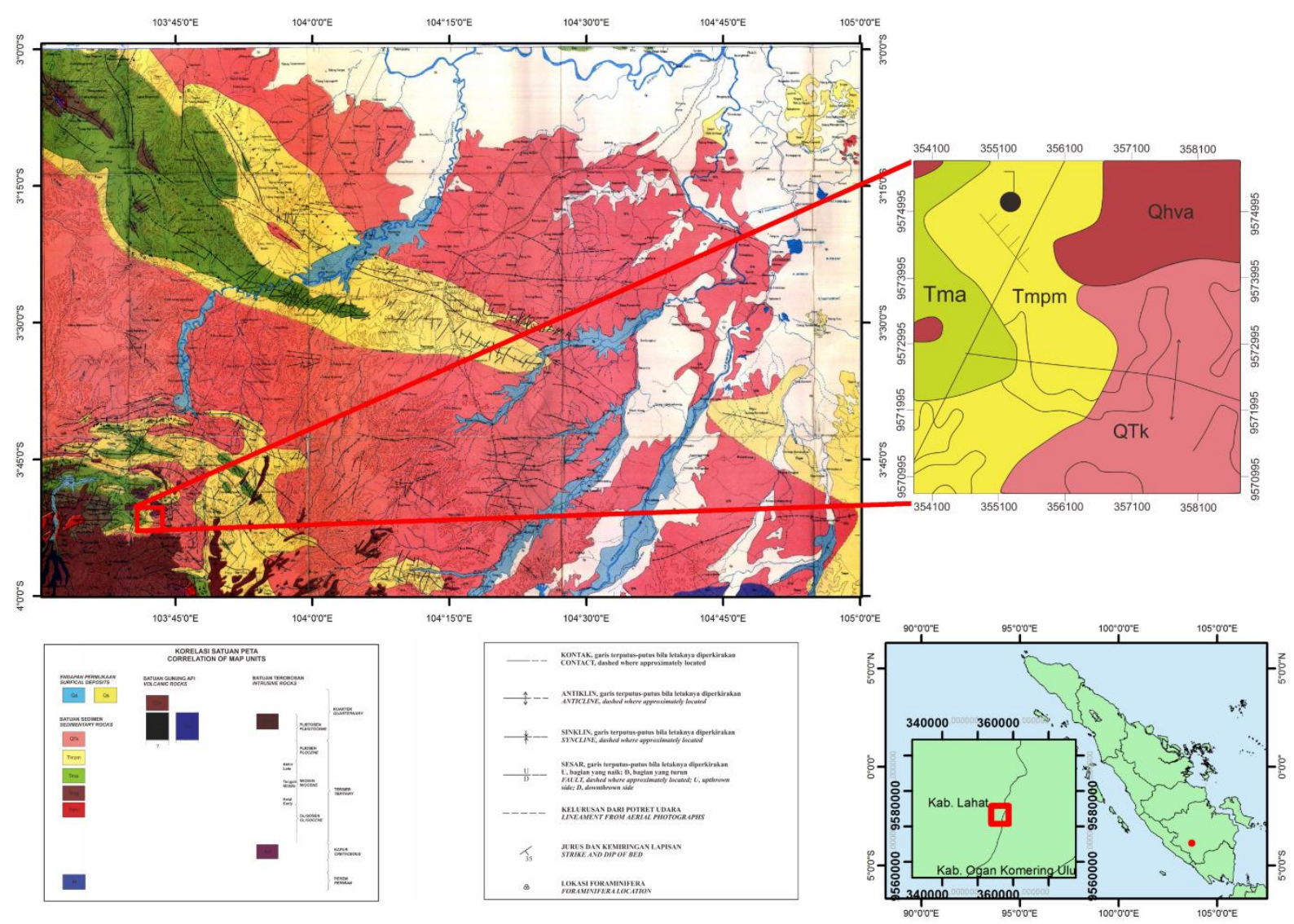

Fig. 2. Geology Map of Lahat Sheet and Research Area Map (Gafoer et al, 1986) 


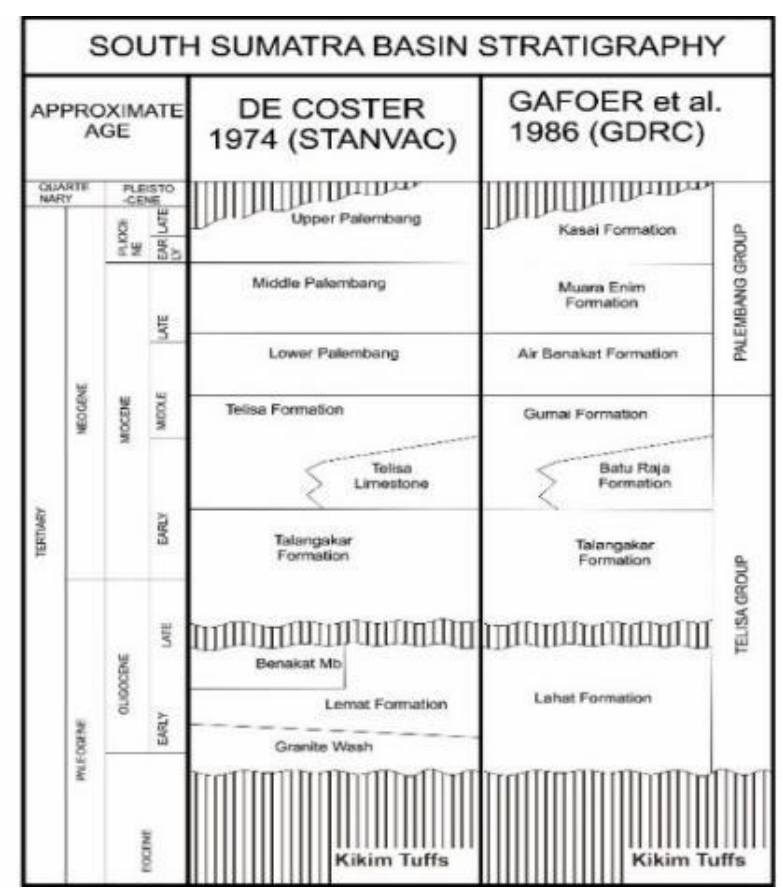

Fig. 3. Regional Stratigraphy of South Sumatra Basin (de Coster, 1974 and Gafoer 1986 in Barber et al., 2002).

(d) Baturaja Formation

Following by deposition of Talang Akar, there apparently was reduction in amount of clastics material being transported to the basin. This factor affected the depositional environment of the Basalt Telisa Limestone (equivalent to Baturaja Formation). In the early stage, extensive platform or bank limestone deposits were form shelfal, and platform portions of the basin. In the later stage, further buildups of detrital, reefal and bank limestone were formed on top of these banks in restricted localities. The deposition of these limestones probably ended when marine transgression resumed. The Basal Telisa Limestone occurs only on the broad shelf and platform areas within the basin.

(e) Gumai Formation

Gumai Formation was deposited during the maximum transgression phase and progresses well throughout the whole basin, in the Early Miocene to the Middle Miocene. The Gumai consisted of fossilliferous marl, the minor amount of sandstone, thin limestone, shale and siltstone.

(f) Air Benakat Formation

Towards the Late Miocene the seawater level was no longer increasing, rather it occurred the decreasing of seawater level globally (regression phase). Air Benakat Formation was deposited in this new phase, laid conformably above the Gumai Formation, it consisted of shale, sandstone, claystone and thin layer of limestone, with a shallow marine environment.

(g) Muara Enim Formation

As the main coal bearing formation in South Sumatera Basin, the Muara Enim Formation turn out to be the main focus of the study. The formation was composed of sandstone, claystone, shale and coal. M ost of the coal is in sub bituminous stage (low rank coal), only in the certain spots (alongside the intrusion of andesite) it turned into high rank coal. The Muara Enim was deposited on the Late Miocene to the Pliocene, in the shallow marine to brackish environment (at the bottom) and delta plain to non-marine environment.

(h) Kasai Formation

The deposition of Kasai Formation considered as the final sedimentary deposition in South Sumatera Basin. It was resulted of the erosion of volcanic products of the Barisan and Tigapuluh Mountains at the Pliocene to the Pleistocene. The lithology of this formation consists of tuffaceous sandstone, gravel, clay and thin layer of coal.

\section{Methods}

The research was conducted through three stages such as (1) collaborative literature study; (2) field observation; (3) laboratory analysis. Collaborative Literature study conduct before going directly to the field, mainly through the scientific papers that have been published by previous researchers. It aims to provide an overview of the general geological condition of the research area. Meanwhile field observation conducted by doing geological mapping within an area of $25 \mathrm{~km}^{2}$. The geological mapping was done to determine the distribution of coal and also the correlation to other rock units obtained in the research area. As for the laboratory analysis, the first thing we should do was sorting the coal samples that previously collected from the field (Fig 10). The next step is working on coal proximate analysis to find out the percentage of ash content and total sulphur along with the calorific value contained in the samples. Based on the results of the analysis, the depositional environment of the research area can be determined by the consisting of ash content, sulphur content and the calorific value.

For coal maceral analysis conducted by showing the relationship value of Tissue Preservation (TPI) 
and Gelification Index (GI) in the research area. Determined by Diesel's equation as follow :

$$
\begin{gathered}
\mathrm{TPI}=\frac{\text { Telinite }+ \text { Telocollinit }+ \text { Psudovitrinit }+ \text { Semifusinit }+ \text { Fusinit }}{\text { Vitrodetrinite }+ \text { Desmokolinit }+ \text { Inertodetrinit }} \\
\mathrm{GI}=\frac{\text { Huminite }+ \text { Gelovitrinit }}{\text { Inertinit }}
\end{gathered}
$$

\section{Result and Discussion}

According to the measuring section analysis performed at several spots of research area, there are claystone, coal and sandstone along with the occurrence of some evolved sedimentary structures such as cross bedding, and graded bedding. Generally, the physical features of coal around the Geramat District were black-colored, dull luster, black stretch and massive compaction, with some additional materials such as resin and pyrite. The result of the proximate analysis represented the percentage value of total sulphur content, ash content and calorific value of coal (Table 1).

\subsection{Depositional Environment}

Coal deposition environment analysis according to the Horne (1987) model of the study area classified in the Transitional Lower Delta Plain depositional environment. The results of lithologic analysis shown that the sandstone is gradually coarsening-fining upwards, supported by the measuring section data which has the same pattern as the depositional environment model (Fig 4).

One of the components in determining the deposition environment is based on the lithology of coal-bearing rocks and sedimentary structures in thestratigraphy sequence. Fig 5 explain comparison between the environmental model of coal deposition in a transitional lower delta plain environment based on Horne (1986) with a stratigraphic measuring section conducted at the point of the study area indicating the compatibility of the constituent lithology so as to interpret the environmental conditions of the coal depositional in the research area. As seen from the sedimentary environment model, it shows the lithologic uptrend from bottom to top.

The transitional lower delta plain environment shows finer grain-size lithologic characteristics than upper delta plain ones, this zone contains brackish water to marine. Such deposition environments are more extensive swamp development in nearly complete filling of interdistributed bays. The subsidence is one of the factors affecting the depositional environment and also the characteristics of the distribution and the quality of coal seams, especially the sulfur content in the research area. The subsidence occurred at a relatively faster velocity resulting in a slower process of precipitation in the sedimentary environment influenced by tectonic activity compared to more stable environments without the effect of subsidence.

The former subsidence caused the the transitional lower delta plain environment has a somewhat lower sulphur content whereas in the upper delta plain environment it has a higher sulphur content. Based on the outcrop profile analysis the research area it is located in the transitional lower delta plan environment with the sub-environment such as crevasse splay, Indistributary bay, levee and channel .

The sediment deposited in crevasse splay deposits are derived from deposition of floods that erode the levee, allowing water to flood into the floodplains around the stream and form crevasse splays deposits. This crevasse will form a pattern and a separate channel system. Based on the stratigraphic cross-sectional measurements in the study area showed the presence of fine grained and massive sandstones layer

Indistributary bay is characterized by claystone and sandstone lithologic with fine grain size. Levee depositts are characterized by the appearance of gray claystone and coarse-grained brown sandstones.

Channel sediments deposited on the facies are coarse-grained deposits and is strongly influenced by the rapid river flow (bedload). Channel deposits consist of river wall debris due to erosion by current flow (Walker and Cant, 1979). The channel deposits is always in motion and on the river base precipitated the coarse grained granules. Characteristics of channel deposits in the study area are seen in stratigraphic cross-sectional measurements in Geramat area which have coarsegrained sandstone lithology composition with cross bedding sedimentary structure.

Table 1. Percentages Data of Total Sulphur, Ash Content and Calorific Value from Five Samples.

\begin{tabular}{cccccc}
\hline No & Lab No. & Sample Marks & $\begin{array}{c}\text { Ash } \\
\% \text { adb }\end{array}$ & $\begin{array}{c}\text { Total Sulphur } \\
\text { \%adb }\end{array}$ & $\begin{array}{c}\text { Gross Calorific Value } \\
\text { cal/g. adb }\end{array}$ \\
\hline 1 & $1443 / 17$ & LP 109 & 71,11 & 0,27 & 953 \\
2 & $1444 / 17$ & LP 24 & 63,45 & 0,22 & 2,520 \\
3 & $1445 / 17$ & LP 49 & 3,16 & 0,21 & 5,645 \\
4 & $1448 / 17$ & LP 8 & 3,72 & 0,35 & 5,676 \\
5 & $1449 / 17$ & LP 34 & 10,88 & 1,54 & 5,325 \\
\hline
\end{tabular}




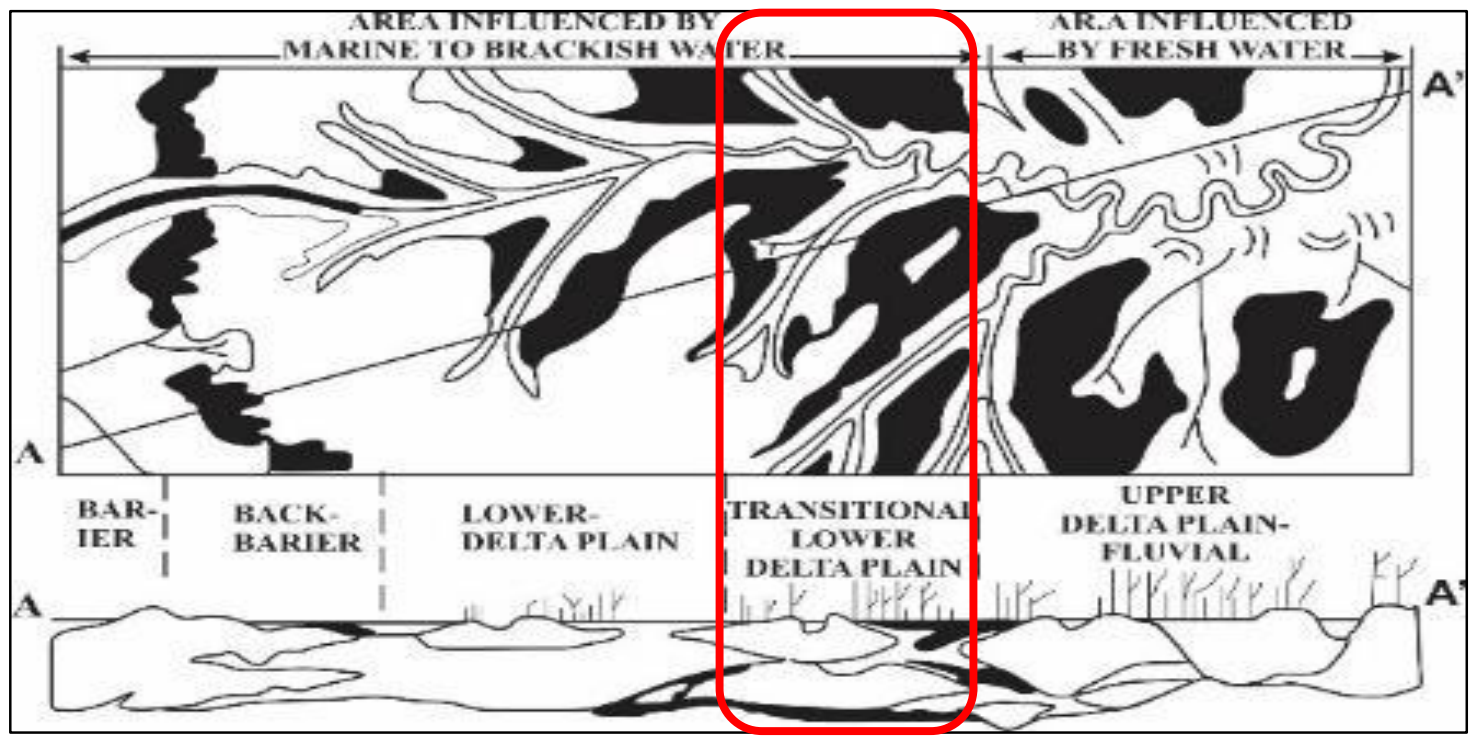

Fig. 4. Depositional environment of research area based on Horne (1987).

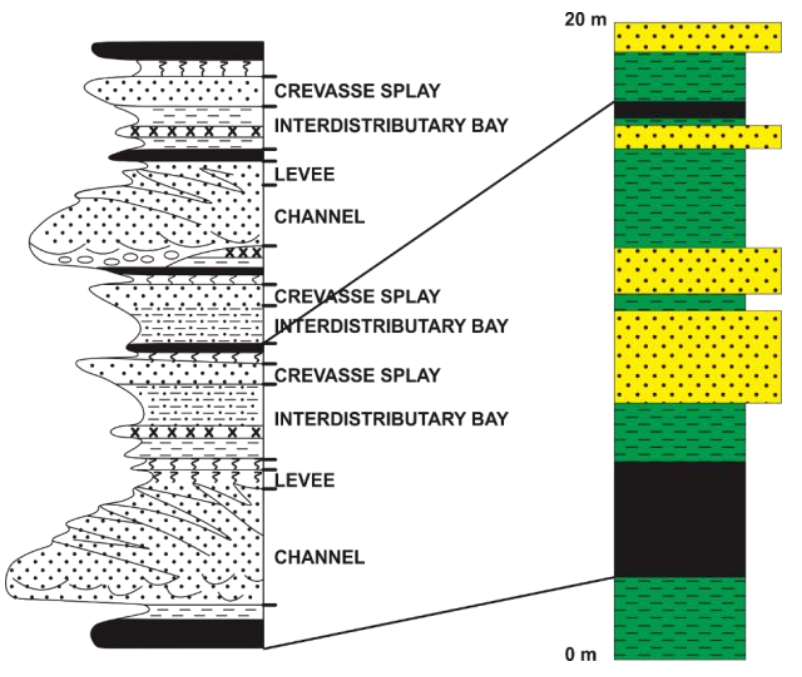

Fig. 5. Identification of transitional lower delta plain depositional environment based on Horne's model (1978)

Based on the depositional environment, it is known that the research area contains low sulphur content because it was not influenced by an intensive sea deposits. It is also proven by the results of data analysis performed wherein total sulphur content contained $<1 \%$. The water's salinity flooding peat is an important factor in determining the sulphur content within the coal as seen in LP 8 (Fig 6) and LP 24 (Fig 7).

\subsection{The Relationship of Coal Quality with Ash Content and Calorific Value}

The result of proximate analysis shows the percentage value of ash content and calories that can be seen in table 1. From the data it can be seen that the higher ash content's value, the lower the calorific value. Otherwise, the lower ash content's value, the higher the calorific value. The example is in LP 109 sample (Fig 8).

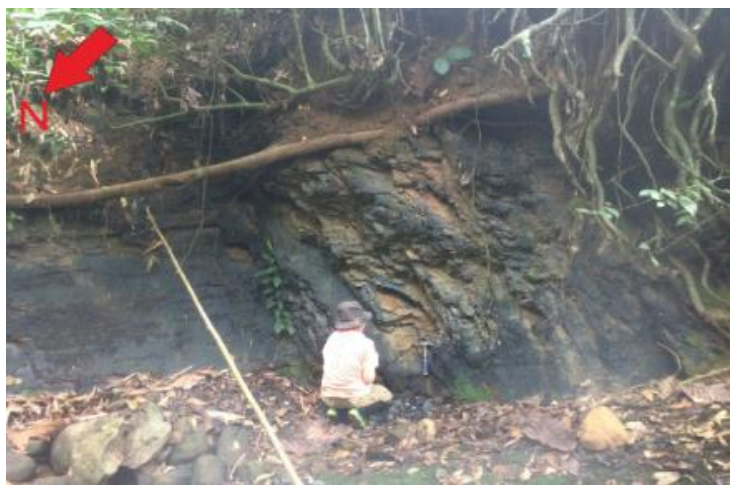

Fig. 6. Coal outcrop contains low sulphur content on LP 8.

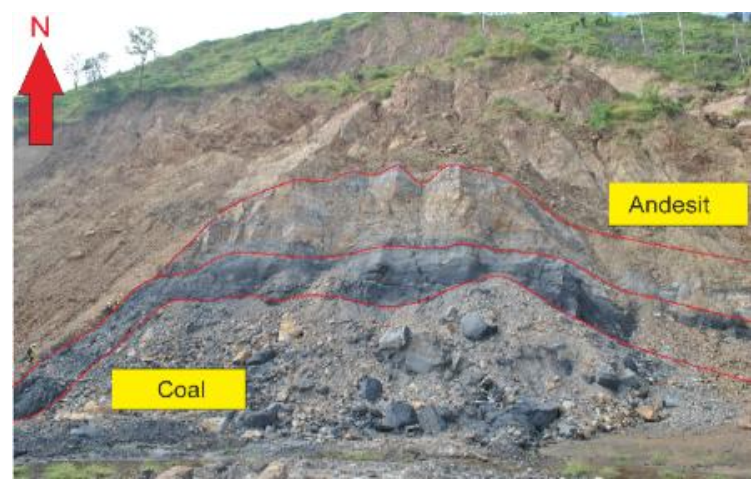

Fig. 7. Coal outcrop contains low sulphur content on LP 24. 


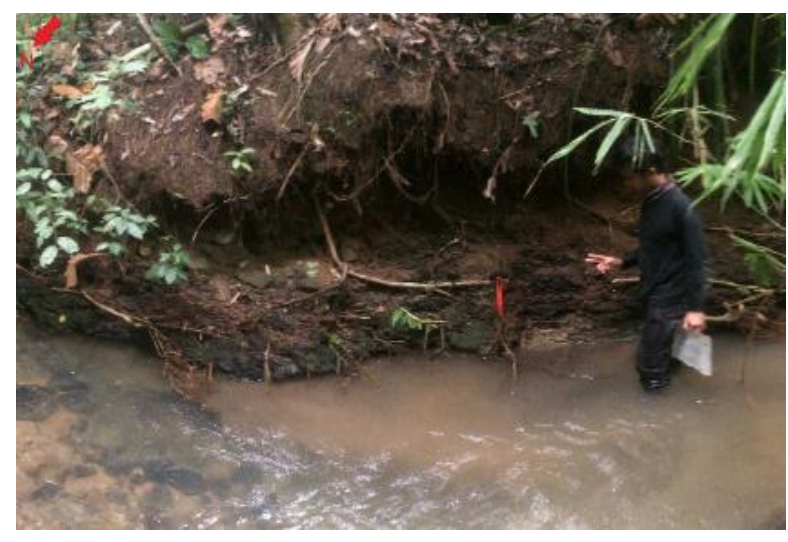

Fig. 8. Coal outcrop of LP 109 with high ash content.

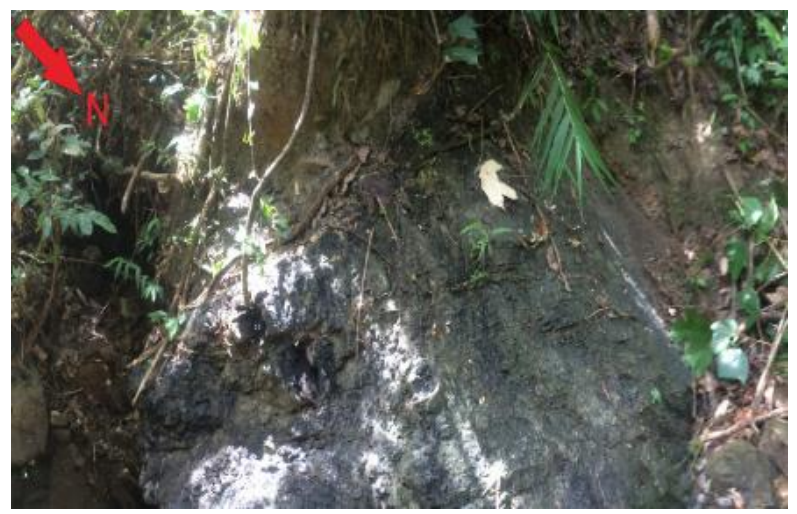

Fig. 9. Coal outcrop contains low ash content LP 49.
The analysis conducted on outcrop LP 49 (Fig 9) resulted in high ash content, based on its acidic depositional environment wherein the presence of mineral matter quite excessive. It caused the high percentage of ash content as $71.11 \%$ adb and low caloric value $953 \mathrm{cal} / \mathrm{g}$, so that the coal on the outcrop is not economically prospect for mining project. As for the LP-S49-AP coal outcrop has low ash content such as 3,16\% adb and high calorific value $5,645 \mathrm{cal} / \mathrm{g}$, indicating the mineral content of the coal outcrop is rather low. The coal cropline can be seen on Fig 10.

\subsection{Depositional Environment interpreted from Maseral}

From the calculation obtained the value of TPI and $\mathrm{Gl}$ on coal shown in Table 2. The TPI value shows a ranging value between $0,15-6,67$. The TPI value indicates a change in plant composition and peat type in the study area caused by condition changes in the depositional environment. As for the $\mathrm{Gl}$ value is high enough to indicates that the oxidation process is not dominant with low inertinite content.

To interpret the coal depositional environment of the research region, the value of TPI and Gl is plotted in the diagram according to Lamberson et al. (1991). The results shows transitional lower delta plain as the coal depositional environment. The transitional lower delta plain environment formed in limnic sub-environment.

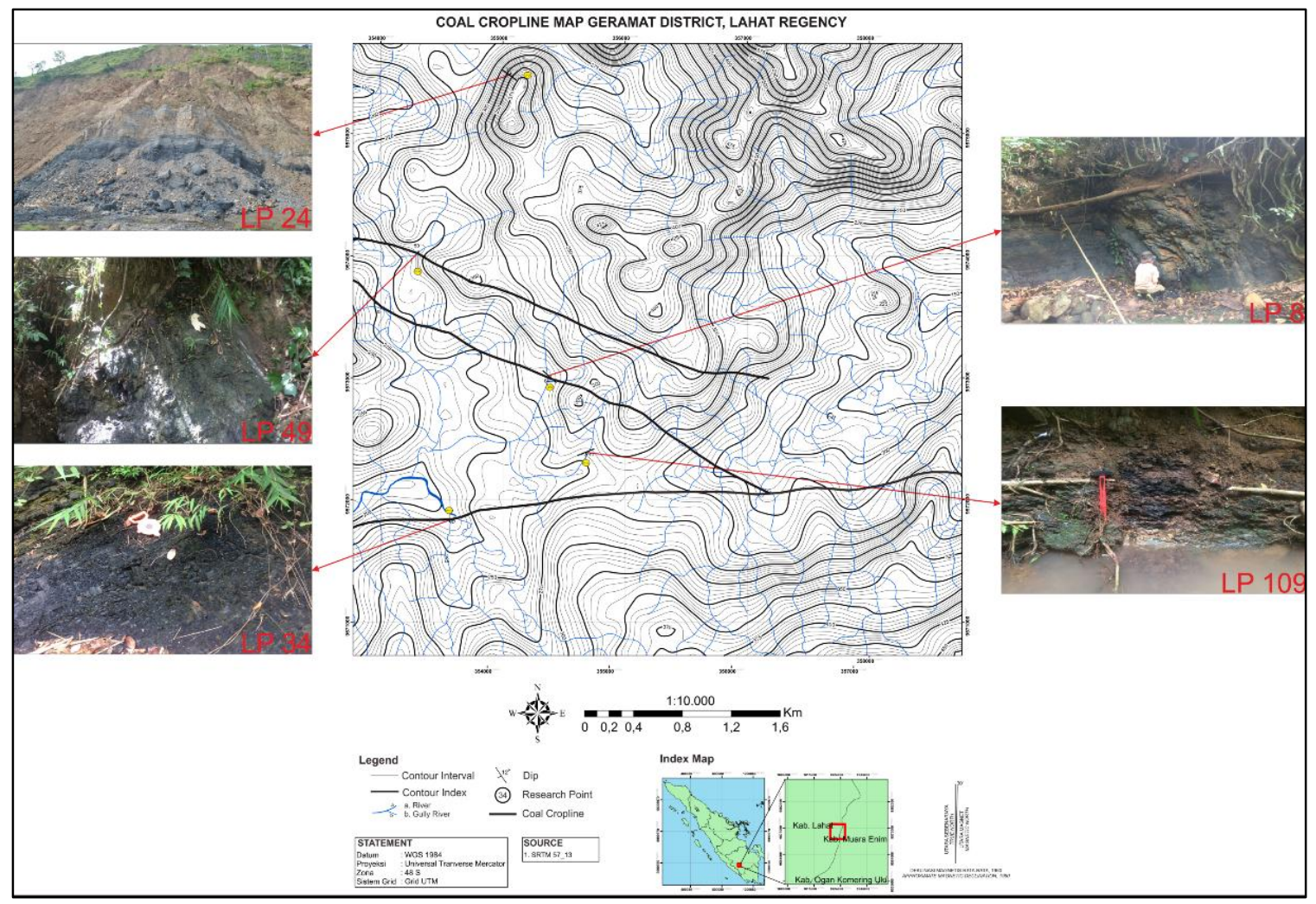

Fig. 10. Coal Cropline Map at Geramat District, Lahat Regency 
Table 2. calculation result of TPI and GI

\begin{tabular}{cccc}
\hline No. & Code Sample & TPI & GI \\
\hline 1 & LP 38 & 0,130 & 7,31 \\
2 & LP 8 & 0,376 & 4,927 \\
3 & LP 24 & 6,67 & 4,42 \\
4 & LP 49 & 0,15 & 10,925 \\
\hline
\end{tabular}

The transitional lower delta plain environment shows low TPI values and relatively high GI values dominated by the detrovitrinite maceral subgroup. This sedimentary environment is dominated by shrub plants compared to timber plants therefore the value of TPI is low. The combination of TPI and Gl can be used to determine the degree of decomposition and plants accumulation rate (Lamberson et al., 1991). Interpretation of the variations in the value of TPI and GI can be seen in (Fig 11).

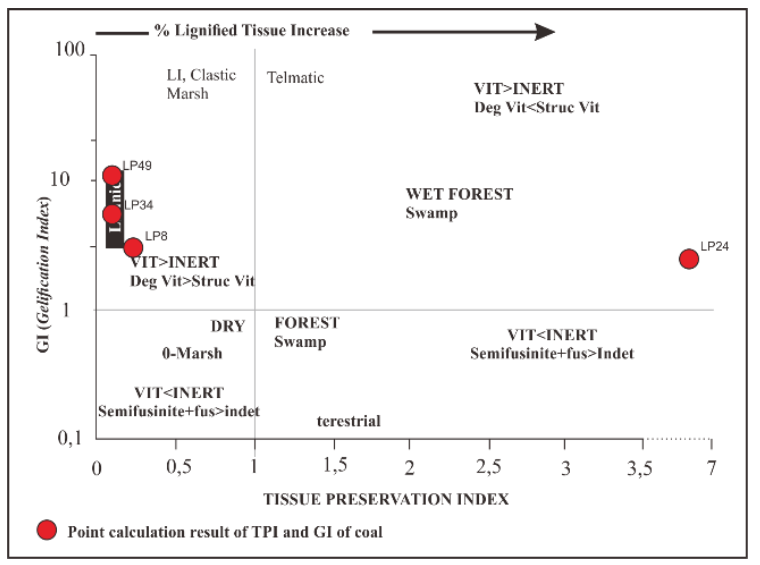

Fig. 11. The interpretation results diagrams in the research area.

From the results of the diagram analysis, it is seen that the $\mathrm{Gl}$ value of coal in the research area is relatively high indicating the depositional environment was in humid or wet conditions in the swamp environment so that the formation of vitrinite will be intensified, with the lack of sea water effect causing the sulphur content in the research area is low.

Unlike the coal outcrop in LP 24 which has a value of TPI reaching 7 this is due to the location of coal is experiencing andesit intrusion that causes coal in this condition is in the non-marine environment with high coal quality, due to the influence of intrusion the pyrite impurity mineral is more dominant than other research sites.

\subsection{Coal Quality}

The analysis of 5 coal samples referring to the American Society for Testing and Materials (ASTM) (1981) suggests that Geramat's coal quality as follows: according to the data percentage value of S109 ash content 71 (\%adb), total sulfur $0.24(\%$ adb), cal orific value 953 (cal/g), S24 ash content 63.4 (\%adb), total sulfur 0.2 (\%adb), calorific value 2.520 (cal /g), S49 ash content 3.72 (\%adb), total sulphur 0.21 (\% adb), calorific value 5,645 (cal/g), S8 ash content 3.72 ( $\%$ adb), total sulfur 0.35 ( $\% \mathrm{adb})$, calorific value $5.676 \mathrm{cal} / \mathrm{g})$, S34 ash content $10.88(\%$ adb) total sulfur 1.54 (\%adb), calorific value 5.325 (cal $/ \mathrm{g})$.The coal quality of research area is classified in low rank coal with caloric value ranged between 953- 5675 (cal/g).

Based on the maceral analysis, showing the maximum vitrinite reflectance value ( $\% \mathrm{Rv} \max$ ) ranged from ( $0.33-0.54 \%$ as seen in Table 3, based in Ward, 1984 the coal rank included in subbituminous - High Volatile Bituminous B.

\section{Conclusions}

Based on this research, it can be concluded as follows :

(a) The research conducted in Geramat District, Lahat Regency, South Sumatra with Muara Enim Formation as a coal-bearing formation.

(b) The sedimentary structures observation at the several outcrops in the field shows that the deposition environment of the research area is in the Transitional Lower Delta Plain phase, telematic sub-environment with low sulphur content.

(c) Organic materials developed in the research area in the form of shrubs with significant vitrinite maceral content in humid or swamp environments.

(d) The coal quality contained in Geramat District shows a high ash content of 71.11 (\% $\mathrm{adb})$ with low sulphur content generally $<1 \%$ and a calorific value of 5,676 (cal/g) which belongs to Sub- a bituminous - High Volatile Bituminous B.

\section{Acknowledgements}

The acknowledgments primary addressed to Mrs. Idarwati, S.T., M.T as a supervising lecturer who is kindly assisted, provided support and gave direction and also big thanks to our friends in the class who helped in discussing and determining the work components on this paper. 
Table 3. Result of Muara Enim Formation maceral analysis in the research area.

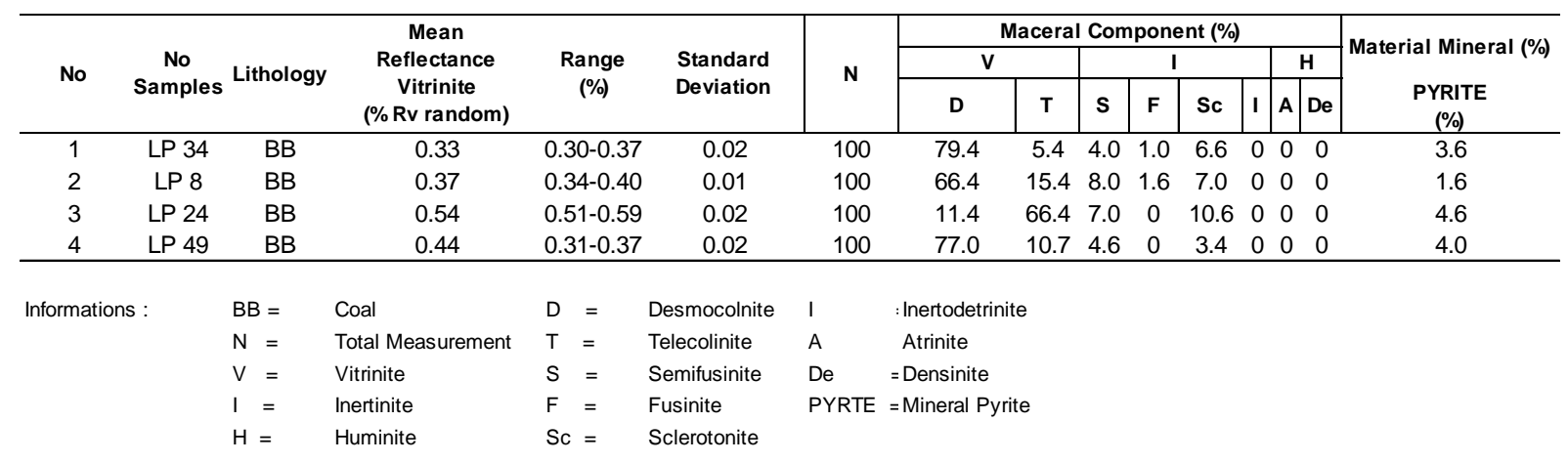

\section{References}

ASTM. 1981. Annual Book of ASTM. Philadelphi, United States of America.

Barber, A.J., Crow and Milsom J.S. 2005. Sumatra : Geology, Resources and Tectonic Evolution. The Geological Society. London.

Casagrande, D.J. 1987. Sulphur in Peat and Coal, in : Scott, A.C. (ed.) Coal And Coal-Bearing Strata : Recent Advances, Geol. Soc. Spec. Publ., No.32, p 87-105.

de Coster G. L. 1974. The Geologi of Central Sumaatera and South Sumatera Basins. Proceeding Indonesian petroleun Assoc, 4th Annual Convention.

Diessel, C.F.K., 1992, Coal - Bearing Depositional System, Spinger - Verlag Berlin. (hal . 423-430).

Gafoer.S, Burhan. G, Dan Purnomo.J. 1986. Laporan Geologi Lembar Palembang, Sumatera., Skala 1 : 250.000. Pusat Penelitian dan Pengembangan Geologi.
Horne, J.C., Ferm, J.C., Caruccio, F.T., Baganz, B.P. 1978, Depositional Models in Coal Exploration and Mining Planning in Appalachian Regioan, AAPG Bulletin 62 p: 2379 - 2411, America.

Lamberson, M.N., Bustin, R.M., Kalkreuth, W . (1991). Lithotype (maceral) composition and variation as correlated with paleowetland environments, Gates Formations, Northeastern British Columbia. Canada; International Journal of Coal Geology 18. p. 87-124

Sulistyana B., Waterman., and Saputra, Dean. 2012. Analisis Pengaruh Lingkungan Pengendapan Batubara Terhadap Kandungan Sulfur Batubara. Proceeding Simposium dan Seminar Geomekanika Ke-1 Tahun 2012.

Ward, C.R. (1986). Review of Mineral Matter in Coal, Australian Coal Geology,Geol.Soc. of Australia, Vol. 6 pp. 87-107.

Walker, R. G., and Cant, D. J. (1979). Facies models 3. Sandy fluvial systems, in Walker, R. G. (ed.), Facies models: Geoscience Canada Reprint Ser. 1 , p. 23-31. 